\title{
Above- and Belowground Carbon Allocation in DeVeloping and MATure Lodgepole Pine Forests in Yellowstone National Park: A Progress REPORT
}

\author{
CREIGHTON M. LITTON $\downarrow$ DENNIS H. KNIGHT \\ DEPARTMENT OF BOTANY + UNIVERSITY OF WYOMING \\ LARAMIE
}

\section{$\downarrow \quad$ INTRODUCTION}

It has been proposed that forests will act as a sink for $\sim 50 \%$ of the anthropogenic $\mathrm{CO}_{2}$ projected to be released into the atmosphere by the year 2050 as global net primary productivity in forests increases (DeLucia et al. 1999). Coniferous forest ecosystems dominate a large portion of the Earth's land area, and fire plays an important role in the natural disturbance regime of these ecosystems (Archibold 1995). Quantifying the components of the carbon cycle during ecosystem recovery from fire is fundamental for determining how fire and changes in fire frequency alter regional and global carbon budgets (Auclair and Carter 1993, Houghton 1996, Burke et al. 1997). Clearly, if we are to model the effects of terrestrial ecosystems on global carbon budgets, we must develop a better understanding of the role that natural disturbance plays in the carbon dynamics of these systems.

Processes that occur after fire may be more important for carbon cycling than the immediate return of carbon to the atmosphere through biomass oxidation (Auclair and Carter 1993). For example, primary productivity following fire is reduced or eliminated until new chlorophyll is synthesized in new leaf area. In addition, aboveground detrital inputs are greatly altered and formerly live roots become available for decomposition. Moreover, litter quality changes with the oxidation of fine fuels; soils and litter become warmer with the removal of overstory shading and a change in albedo; and soils become wetter because of essentially no post-fire transpiration and very little interception of rain and snow. These changes can increase decomposition and soil respiration (Burke et al. 1997), releasing as much as three times more carbon to the atmosphere as the amount released by the initial fire (Auclair and Carter 1993). Notably, carbon is assimilated by new plant growth in fire-adapted ecosystems, with perhaps little net effect on atmospheric $\mathrm{CO}_{2}$ (Crutzen and Goldhammer 1993).

In addition to large effects on carbon budgets at the stand scale, fire and landscape variables interact to produce a mosaic of different vegetation types (Anderson and Romme 1991, Turner et al. 1997a and b, Foster et al. 1998). The resulting spatial heterogeneity in tree density, herbaceous cover, and species composition in Yellowstone National Park (YNP) will influence primary production and carbon storage for many years. Therefore, to determine the long-term effects of fire on carbon release and storage following fire, information is needed on how processes differ among sites as a function of community structure and stand age. YNP is an ideal study area for this kind of research. 
Our objective is to answer two questions:

1) How does the relative abundance of trees, shrubs, and herbs influence above- and belowground carbon storage and flux values in young post-fire stands?

2) How do above- and belowground carbon storage and fluxes in young post-fire stands differ from those in nearby mature forests?

\section{METHODS}

Study sites: Sixteen permanent plots were located in the summer of 2000 on the subalpine plateau of YNP using a full factorial design: four replicates of four forest types (namely, low, moderate, and high densities of lodgepole pine trees in 12-yr-old post-fire forests, plus nearby mature stands, all with comparable edaphic and topographic conditions). Each plot is approximately 0.5 ha in size and consists of three $1 \times 20 \mathrm{~m}$ permanent transects for the estimation of soil $\mathrm{CO}_{2}$ efflux, six $1 \mathrm{~m}^{2}$ litterfall traps for the estimation of litterfall rates, and five $2 \mathrm{x}$ $50 \mathrm{~m}$ temporary transects for the measurement of sapling density, herbaceous cover, and pre-fire basal area.

\begin{abstract}
Aboveground Carbon Allocation: Aboveground net primary productivity (ANPP) for the year 2000 will be estimated for all species and growth-forms (tree, herbaceous and shrub) in each plot using existing allometric equations and commonly employed harvesting techniques. This work will be completed in the spring of 2001, as leaf and twig expansion in 2000 was not complete until September, after our field season had ended. Measurements of herbaceous and shrub ANPP were made at approximate peak biomass during the summer of 2000.
\end{abstract}

Allometric equations for the estimation of tree ANPP in young stands were developed during the summer of $1999\left(\mathrm{r}^{2}\right.$ values from $\left.0.73-0.87\right)$. Harvested trees in 2001 will be used to validate the current allometric equations and to produce new equations for the estimation of tree ANPP in those sites where that seems necessary. The ANPP for large trees in mature forests will be estimated using regression models developed by Pearson et al. (1984), or modifications of those equations if necessary. Additional trees will be sampled as needed in June of 2001.
Herbaceous and shrub ANPP will be estimated by using cover values (by species) obtained during the summer of 2000 and allometric equations between cover and ANPP for each species. These allometric equations were derived by species during the summer of $1999\left(r^{2}\right.$ values from $\left.0.84-0.99\right)$.

Belowground Carbon Allocation: The Total Belowground Carbon Allocation (TBCA) method of Raich and Nadelhoffer (1989) was introduced as an alternative to the estimation of belowground carbon allocation by plants. TBCA consists of coarse and fine root production (i.e., BNPP), root construction and maintenance respiration, and carbon allocated to root exudates and mycorrhizae (Raich and Nadelhoffer 1989, Ryan 1991, Gower et al. 1996). This carbon balance approach is derived assuming that carbon stored in soil, roots, and litter is at steady state and, therefore, soil respiration $\left(\mathrm{F}_{\mathrm{S}}\right)$ must equal carbon inputs to the soil in the form of litterfall $\left(\mathrm{F}_{\mathrm{A}}\right)$ and TBCA: $\mathbf{F}_{\mathrm{S}}=\mathbf{T B C A}+\mathbf{F}_{\mathrm{A}}$; solving for TBCA yields: $\mathbf{T B C A}=\mathbf{F}_{\mathrm{S}}-\mathbf{F}_{\mathrm{A}}$.

Gower et al. (1996) criticized this approach because of the assumption that soil carbon pools are in a steady state. We are addressing this weakness using the approach of Giardina and Ryan (submitted) by estimating changes in soil, litter, and root carbon pools. Thus, annual TBCA will be estimated as:

$T B C A=F_{S}-F_{A}+\left(\Delta C_{S}+\Delta C_{R}+\Delta C_{L}-\Delta C_{D C W R}\right)$

where $\mathrm{F}_{\mathrm{S}}=\mathrm{CO}_{2}$ efflux from soil, $\mathrm{F}_{\mathrm{A}}=$ aboveground litterfall, $\mathrm{C}_{\mathrm{S}}=$ soil organic matter carbon pool, $\mathrm{C}_{\mathrm{R}}=$ root c arbon pool (post-1988), $\mathrm{C}_{\mathrm{L}}=1$ itter carbon pool, and $\mathrm{C}_{\mathrm{DCWR}}=$ dead coarse woody root carbon pool (pre1988).

\section{$\uparrow \quad$ RESUlts}

Preliminary data have been collected and analyzed for three sites that burned in 1988. These sites cover a range of tree densities (low, moderate, and high tree densities) and have herbaceous and shrub cover values that decline with increasing tree density. Total ANPP increased with increasing tree density in these three stands (Figure 1). In addition, as tree density increased, the proportion of ANPP contributed by herbaceous plants decreased. 


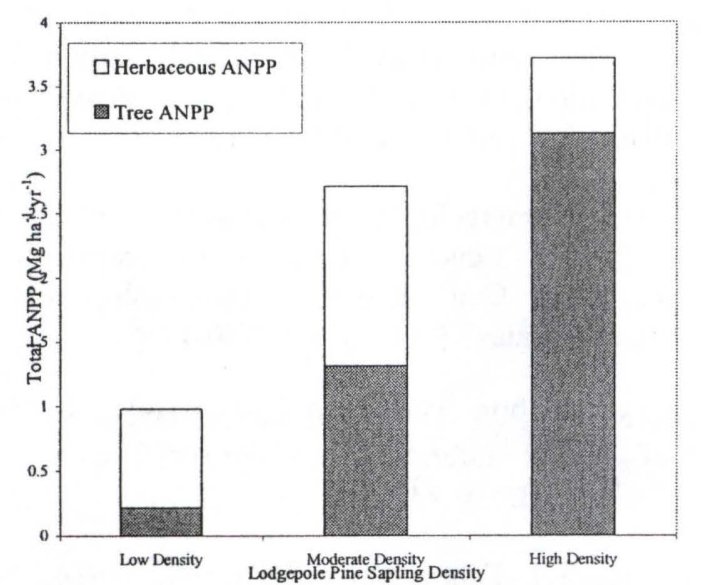

Figure 1. Total ANPP for plots representing different stand structures in YNP. ANPP was determined using dimension analysis and traditional allometric techniques on 120 harvested saplings.

$\mathrm{CO}_{2}$ efflux varied with stand structure $(\mathrm{P}<$ 0.01 ). Mean flux for the high-density stand was 0.57 $\mathrm{kg} \mathrm{CO}_{2} \mathrm{~m}^{-2} \mathrm{yr}^{-1}$, compared with 0.43 and $0.41 \mathrm{~kg} \mathrm{CO}_{2}$ $\mathrm{m}^{-2} \mathrm{yr}^{-1}$ for the moderate and low density stands, respectively. $\mathrm{CO}_{2}$ efflux decreased over time as soils dried $(\mathrm{P}<0.01)$, from $0.65 \mathrm{~kg} \mathrm{CO}_{2} \mathrm{~m}^{-2} \mathrm{yr}^{-1}$ on June 28 to $0.22 \mathrm{~kg} \mathrm{CO}_{2} \mathrm{~m}^{-2} \mathrm{yr}^{-1}$ on October 9. In general, $\mathrm{CO}_{2}$ efflux was highest in the high density stand, intermediate in the moderate density stand, and lowest in the low density stand (Figure 2).

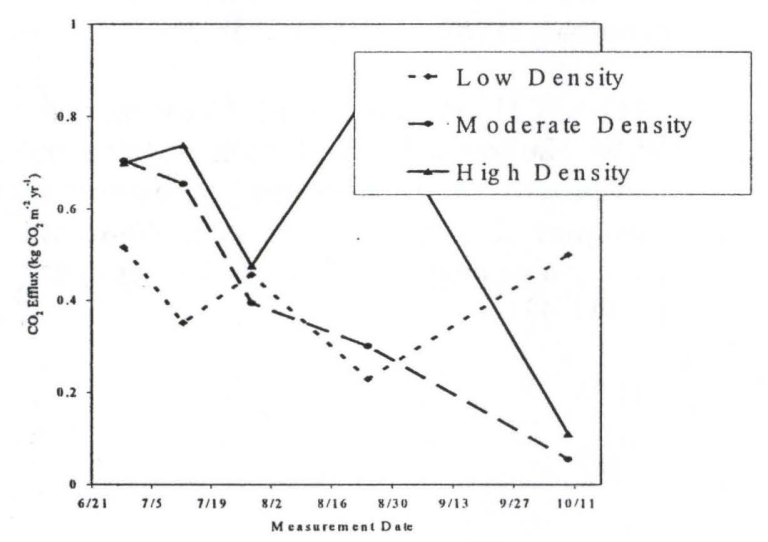

Figure 2. Mean $\mathrm{CO}_{2}$ efflux values $\left(\mathrm{kg} \mathrm{CO}_{2} \mathrm{~m}^{-2} \mathrm{yr}^{-1}\right)$ for low, moderate and high density stands.

Total litterfall increased with tree density, although no significant differences were seen in total litterfall rates (Figure 3). The percentage of litter in different components varied across sites, with needle litterfall more important in the high tree density stand; and grass, sedge, and forb litterfall more important in the low tree density stand.

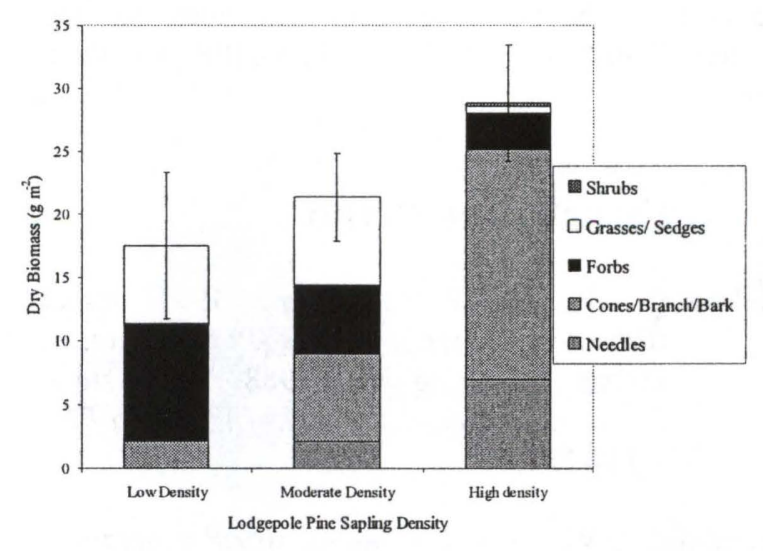

Figure 3. Litterfall rates for plots representing different stand structures in YNP. Litterfall was

collected in twelve $1 \mathrm{~m}^{2}$ traps for each stand (Bars indicate \pm 1 S.E. for total litterfall).

\section{$\uparrow$ DISCUSSION}

Our preliminary data indicate that differences do exist in total carbon allocation as a function of initial tree density following fire. ANPP, and the proportion of ANPP attributable to trees and herbs, differs in stands of different tree density. Moreover, significant differences in soil respiration in stands of different tree density, along with no significant differences in litterfall rates, indicate important differences in TBCA. The original TBCA methodology assumes a steady state in soil, root, and litter carbon pools, which we cannot assume in our rapidly aggrading stands. However, changes in these carbon pools are likely to be small over a 2-3 year period.

We are continuing our research in YNP to further elucidate patterns in TBCA and ANPP as a function of post-fire stand structure. In addition, carbon storage and flux values will be estimated for mature lodgepole pine forests to determine how these values differ from the 12 -yr-old stands that were initiated after the fires of 1988 .

\section{ACKNOWLEDGEMENTS}

Dr. Monica G. Turner, Dr. William H. Romme, Dr. Michael G. Ryan and Dr. Daniel B. Tinker contributed logistical and intellectual support for this study. Laboratory facilities and housing were provided by the University of Wyoming - National Park Service Research Center. We would like to thank everyone on the 1999 and 2000 summer field crews. Funding for this project was provided by 
grants from the National Science Foundation, the Mellon Foundation, and the UW-NPS Research Center.

\section{LITERATURE CITED}

Anderson, J.A., and W.H. Romme. 1991. Initial floristics in lodgepole pine (Pinus contorta) forests following the 1988 Yellowstone fires. International Journal of Wildland Fire 1:119-124.

Archibold, O.W. 1995. Ecology of world vegetation. Chapman and Hall, London. 510 p.

Auclair, A.N.D., and T.B. Carter. 1993. Forest wildfires as a recent source of $\mathrm{CO} 2$ at northern latitudes. Canadian Journal of Forest Research 23:1528-1536.

Burke, R.A., R.G. Zepp, M.A. Tarr, W.L. Miller, and B.J. Stocks. 1997. Effect of fire on soilatmosphere exchange of methane and carbon dioxide in Canadian boreal forest sites. Journal of Geophysical Research 102:29,298-29,300.

Crutzen, P.J., and J.G. Goldhammer, editors. 1993. Fire in the environment: the ecological, atmospheric, and climatic importance of vegetation fires. John Wiley \& Sons, New York.

DeLucia, E.H., J.G. Hamilton, S.L. Naidu, R.B. Thomas, J.A. Andrews, A. Finzi, M. Lavine, R. Matamala, J.E. Mohan, G.R. Hendrey and W.H. Schlesinger. 1999. Net primary production of a forest ecosystem with experimental $\mathrm{CO}_{2}$ enrichment. Science 284: 1177-1179.

Foster, D.R., D.H. Knight and J.F. Franklin. 1998. Landscape patterns and legacies resulting from large, infrequent forest disturbances. Ecosystems 1: 497-510.
Giardina, C. and M. R yan. S oil surface $\mathrm{CO}_{2}$ e fflux, litterfall, and total belowground carbon allocation in a fast growing Eucalyptus plantation. Submitted to Ecology.

Gower, S.T., S. Pongracic and J.J. Landsberg. 1996. A global trend in belowground carbon allocation: Can we use the relationship at smaller scales? Ecology 77: 1750-1755.

Houghton, R. A. 1996. Terrestrial sources and sinks of carbon inferred from terrestrial data. Tellus 48B:420-432.

Pearson, J.A., T.J. Fahey and D.H. Knight. 1984. Biomass and leaf area in contrasting lodgepole pine forests. Can. J. For. Res. 14: 259-265.

Raich, J.W. and K.J. Nadelhoffer. 1989. Belowground carbon allocation in forest ecosystems: Global trends. Ecology 70: 1346-1354.

Ryan, M. G. 1991. A simple method for e stimating gross carbon budgets for vegetation in forest ecosystems. Tree Physiology 9: 255-266.

Turner, M.G., V.H. Dale and E.E. Everham, III. 1997a. Crown fires, hurricanes and volcanoes: a comparison a mong large-scale disturbances. BioScience 47:758-768.

Turner, M.G., W.H. Romme, R.H. Gardner, and W.W. Hargrove. 1997b. Effects of fire size and pattern on early postfire succession in subalpine forests of Yellowstone National Park, Wyoming. Ecological Monographs 67:411-433. 